WellBeing International

WBI Studies Repository

2001

\title{
The Ethical Limits of Domestication: A Critique of Henry Heffner's
} Arguments

\author{
Colin Allen \\ Texas A\&M University \\ Marc Bekoff \\ University of Colorado \\ Lori Gruen \\ Wesleyan University
}

Follow this and additional works at: https://www.wellbeingintlstudiesrepository.org/acwp_arte

Part of the Animal Experimentation and Research Commons, Animal Studies Commons, and the Other Animal Sciences Commons

\section{Recommended Citation}

Allen, C., Bekoff, M., \& Gruen, L. (2001). The ethical limits of domestication: A critique of Henry Heffner's arguments. Anthrozoös, 14(3), 130-134.

This material is brought to you for free and open access by WellBeing International. It has been accepted for inclusion by an authorized administrator of the WBI Studies Repository. For more information, please contact wbisr-info@wellbeingintl.org.

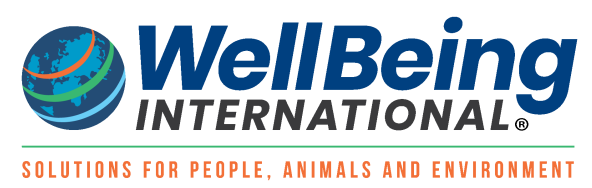




\title{
The Ethical Limits of Domestication: A Critique of Henry Heffner's Arguments
}

\author{
Colin Allen ${ }^{1}$, Marc Bekoff ${ }^{2}$, and Lori Gruen ${ }^{3}$ \\ ${ }^{1}$ Texas A\&M University \\ ${ }^{2}$ University of Colorado \\ ${ }^{3}$ Wesleyan University
}

\begin{abstract}
$\underline{\text { ABSTRACT }}$
Henry E. Heffner argues that "animals bred for research are properly viewed as animals who have successfully invaded the laboratory niche, relying heavily on kin selection to perpetuate their genes." (1999, p. 134). This view of human-animal interactions is the cornerstone of his defense of animal experimentation in two widely-distributed papers (Heffner 1999, 2001). We argue that Heffner's defense lacks adequate attention to ethical distinctions and principles.
\end{abstract}

\section{INTRODUCTION}

Many scientists support expanded efforts to protect research animals from pain and suffering, but there remains a sizable contingent of scientists who feel the need to defend the status quo. One such scientist is psychologist Henry Heffner of the University of Toledo. Heffner has presented his views of the ethics of animal research in two recent articles (Heffner 1999, 2001). Heffner's core argument is that laboratory animals have entered into a symbiotic relationship with human beings, a relationship that is mutually beneficial, and whose termination "would lead to the extinction of entire species" (Heffner 1999, p. 138). According to Heffner:

\begin{abstract}
Some animals, such as cats and dogs, had already established mutualistic relationships with us and their movement into the laboratory represents an expansion of this relationship. Other animals, such as macaques and chimpanzees, have no close relationship with us outside the laboratory. However, chimpanzees are currently in danger of becoming extinct and the best chance for their survival may be to establish a mutualistic relationship with us, i.e., to become domesticated. Thus, one obvious survival strategy for chimpanzees would be to expand their use of kin selection and, capitalizing on their genetic similarity with humans, become essential to medical research thus increasing their own ability to survive - as well as ours. (1999, p. 133)
\end{abstract}

In his second article (Heffner 2001), Heffner describes the approach he takes to justifying animal experimentation in the classroom. Heffner's classroom strategy has four stages: (1) establish that animal research benefits humans; (2) establish that animals themselves lack morality; (3) establish that animal research is a symbiotic relationship that benefits animals; (4) establish that harm is morally acceptable if it provides sufficient benefits. Having outlined his approach to teaching, Heffner reports that "The few students opposed to the use of animals by humans usually have little to say." We can think of many 
reasons why students who disagree with Heffner's views might choose to remain silent in his classroom, but there being nothing to say is almost certainly not one of them. Indeed, Heffner's one-sided presentation of the issues would unnerve most students who would disagree with him. Further, some might see the very same holes in his argument that we describe below but choose not to challenge the authority of their instructor. And given that students who complain are often misunderstood and tagged "anti-science," those hoping for a future career in science may be right to remain cautiously silent.

We believe that animal experimentation needs to be carefully justified. The poor arguments offered by Heffner do everyone a disservice, not least to his students, but also to the professional scientists to whom his articles are directed. In this short commentary we describe the problems with his presentation in each of the four areas and indicate what is required for a more sophisticated approach.

\section{(1) BENEFITS TO HUMANS}

"The first step," writes Heffner, "in addressing the use of animals is to point out how much animal research benefits humans" (Heffner 2001). In both his articles, Heffner follows many other defenders of invasive animal research in claiming that Pasteur's use of animals in his work on anthrax and rabies was crucial to the acceptance of the germ theory of disease. Claiming that "virtually all understanding of how the brain works is based on animal research" (2001), Heffner's general point is that animal experimentation has beneficially expanded human knowledge.

While it is historically undeniable that many developments in neuroscience and medicine were made by scientists who conducted invasive animal research, what's missing in Heffner's presentation is a discussion of whether the use of animals is scientifically necessary. Two points are worth making here.

First, the very same work could have been conducted on humans but for the fact that it would have been considered unethical to do such work on humans. There was no scientific necessity for Pasteur to use nonhuman animals, exposing them to anthrax or rabies and then sacrificing them to obtain brain tissue, for the very same procedures could have been applied to humans. It was purely and simply an ethical or practical decision not to conduct such work on humans. The same is true of most if not all research conducted on animals; humans could be substituted without loss (and with probable gain) of scientific validity. Therefore, to turn around and attempt to give an ethical justification of the animal research on the grounds of its historical role in providing benefits to humans is ethically circular for it presupposes the very point at issue, namely that it is ethically acceptable to do certain things to nonhuman animals that are unacceptable when done to humans.

Second, many of those who practiced invasive animal research (even some of Pasteur's contemporaries) have come to realize that much of it was not or is no longer scientifically necessary, for other methods (besides human testing) are available. In some cases the animal work is also scientifically insufficient, for the results are not directly transferable to humans. A sophisticated discussion of this issue would not attempt to justify invasive animal research wholesale, as Heffner does, but would consider the different cases that can be made for different experiments.

\section{(2) ANIMAL MORALITY}

Heffner (2001) writes "Those who argue against our use of animals in research often hold humans in low regard while exalting animals, a viewpoint that makes it easier to accept limits on research." This is, of course, to set up a straw man. A more sophisticated treatment would recognize the very great extent to which those who argue against animal research are deeply concerned with respect for sentience wherever it is found. Nevertheless, Heffner sets himself the task of simultaneously raising the regard of his students for humans while lowering their regard for nonhuman animals. He attempts to accomplish the 
first part of this task by downplaying the global environmental consequences of human behavior (presumably he thinks that low regard for humans stems from dismay about the consequences of human behavior on the environment) and he attempts to accomplish the second part by making students "aware of the cruelty and waste of nature" (presumably he thinks that showing animals to be wasteful will cause students to have a lowered opinion of their moral worth).

The distortion of facts and the logical gaps in Heffner's presentation are enough to leave anyone speechless, including his silent students. Regarding overpopulation, Heffner (2001) writes: "overpopulation is not a problem in many countries as human reproductive rates in industrialized countries, including the United States, are now below replacement level, a fact that should reduce human pressure on the environment in general and animal habitats in particular." But the connection between reproductive rate and population growth in industrialized countries is a tenuous one, because of immigration from countries with higher birth rates. Furthermore, the entirely understandable migration of people from poorer regions of the earth to areas of vastly higher per capita resource consumption, along with the overall raising of living standards in most countries, continues to increase pressure on resources worldwide. Heffner also reports that forest area in the U.S. has increased in the last 50 years, but a more nuanced view would consider the effects of human behavior on forest diversity, not just acreage. He writes that "the large number of deer found in suburbia is not due to human encroachment into deer habitats, but to our creation of ideal habitats for deer" but he fails to mention the effect of human eradication of the natural predators of deer. All of this, however, is of dubious relevance to the argument about invasive animal research. Even if Heffner is right that environmental concerns are overblown and humans are not as destructive as many believe, it doesn't follow that whatever humans do in the name of scientific research is morally acceptable. Whether the environment is on its way up or on its way down should not affect the moral evaluation of our treatment of laboratory animals.

It is similarly hard to fathom why Heffner thinks the fact that killer whales wastefully do not eat all the sperm whales that they kill, or that they eat just the tongues of minke whales leaving them to die, has any relevance whatsoever to what it is permissible for humans to do to rats and other animals in a laboratory setting. (Nor is it clear why the assertion that whales are wasteful should cause us to think any differently about rats.) Heffner's judgmental use of the term "waste" is presumably designed to make students think less of nonhuman animals, but it is difficult to turn this into a sound argument for reduced moral concern for animals. There are a couple of principles that might be offered to bridge the gap. First, Heffner's unstated general thesis might be that animals that behave wastefully or without moral consideration for others (regardless of whether this is because they are acting immorally or acting amorally) do not themselves deserve moral consideration. But this is entirely implausible for it would follow that humans, who frequently behave wastefully and without moral consideration for others, do not themselves deserve moral consideration. (If this is indeed Heffner's principle, its extension to all members of a group from the wastefulness of a few is even more stunning. It is as if having a remote cousin who is a murderer - as everyone does! - determines the kind of moral consideration to which one is entitled.)

The only other plausible candidate for Heffner's unstated principle is the Kantian line that only organisms who can conceive of morality are themselves worthy of moral consideration, with his examples presumably designed to show that nonhuman animals acting wastefully are apparently unable to conceive of morality, therefore acting amorally. While the Kantian line has its defenders, it nonetheless strikes many people as implausible, as it excludes all humans who cannot engage in Kantian rationality, for example, infants and people with severe mental disabilities. Lacking in Heffner's discussion is any attention to the distinction that has been drawn by many ethicists between moral agents - those who have the capacities to make moral decisions and act morally (and immorally) - and moral patients - those who lack such capacities, and whose own actions are thus essentially amoral, but who nonetheless 
experience pain and pleasure and thus deserve moral consideration (see many of the essays in Bekoff 1998, as well as Sapontzis 1987, Rollin 1992, Gruen 1993, Bekoff 2000, and Varner 2000 for reviews of this issue in the context of animal ethics). An adequate treatment of animal ethics in the classroom would discuss these issues by drawing on the large and sophisticated literature on moral considerability, rather than leaving the students to draw unrigorous conclusions from loose premises about animal wastefulness, and would include presentation of the biological roots of moral behavior in humans and other species.

\section{(3) ANIMAL BENEFITS}

Heffner maintains that laboratory research is a mutualistic (symbiotic) relationship benefiting both humans and laboratory animals and as such it is a form of domestication. The "benefits" to animals are measured by increases in their numbers, geographic distribution, and phenotypic diversity. According to Heffner (1999, p. 134): "animals bred for research are properly viewed as animals that have successfully invaded the laboratory niche, relying heavily on kin selection to perpetuate their genes."

The presumption here, which is repeated in his 2001 article, is that perpetuating genes is the sole relevant factor for the ethical evaluation of animal research. This fails to give students the tools required to think about animal experimentation in the careful way that such a topic deserves. A proper treatment would start by distinguishing benefits to individuals from benefits to groups of individuals, and would go on to consider the point of moral theory with respect to each of these ends, rather than simply relying on the principle that increasing the species' biological distribution is the sole important good. It should also be pointed out that little that is learned in animal experimentation is ever used for the benefit of the animals who were used, or their relatives.

An obvious objection to the argument that animal experimentation is justified by reproductive benefits to members of the group stems from the fact that apparently analogous reasoning could have been applied to Africans in human slavery: their numbers, geographic distribution and phenotypic diversity were all increased. Clearly this does not justify the practice. Heffner did not anticipate this objection in the published version of his 1999 paper, but in a new footnote added to an updated version of the paper (available from his web site cited below) he explicitly rejects the comparison. He writes:

The validity of an ecological niche can be determined by asking whether abolishing that niche would reduce the population size. Clearly, abolishing domestication would lead to a massive reduction, if not outright extinction, of domestic animals. Slavery, on the other hand, is not a valid ecological niche as its abolition does not result in a decline in the numbers of former slaves and their offspring. Thus, the arguments justifying domestication cannot be used to justify slavery.

Even if we accept the questionable premise that the research laboratory is a niche and that laboratory animals have been "domesticated," this rearguard action fails for at least two reasons. First, Heffner's principle is vulnerable to the objection that if slavery was a "valid ecological niche," its practice would be justified. If, for example, released slaves were condemned to a level of poverty that entailed decreased survivorship among them, then on Heffner's principle it would be justifiable to keep them as slaves. It would take us too far afield here to rehearse the many good reasons for thinking that human slavery would not be justified even under these circumstances, but the existence of such reasons shows the inadequacy of Heffner's principle as a basis for moral evaluation of human practice. Indeed, if human action (or inaction) is allowed to determine what counts as a valid ecological niche (as Heffner's principle clearly allows), then the principle would allow one to contrive conditions in such a way as to make the survivorship of slaves higher than that of released slaves, and use this as a means to justify the practice. 
Heffner might respond that former slaveholders are morally obliged to prevent conditions that would result in massive mortality among their former slaves. But this suggestion brings us to the second reason for rejecting Heffner's claim that his argument supports invasive animal research without endorsing slavery: namely, he has neglected to establish that humans would have no obligations to animals no longer used in research. If it is true that "abolishing domestication would lead to a massive reduction, if not outright extinction, of domestic animals," this fact has much to do with human behavior, and specifically a lack of commitment to the well-being of those animals and their descendants. Likewise, if chimpanzees have a better chance of surviving as laboratory animals than in the wild, as Heffner suggested in the passage quoted in our introduction, this has more to do with human destruction of natural chimpanzee habitat than with any other factor.

Heffner misrepresents his opponents when he writes that "the animal rights movement aims to abolish all interactions between humans and animals" (1999, p. 137). Nonetheless, he is alert to the suggestion made above, that humans might have an obligation to care for laboratory animals if research were suspended. He writes, "to argue that we should continue to care for domestic animals without making use of them is a threat to their survival; to do so would reduce their relationship with us to, at best, one of commensalism which, in times of hardship, would degenerate into parasitism - with humans as the host. Such a state of affairs would not be conducive to their long-term survival" (1999, p. 137). But of course this does not constitute an argument that things must turn out this way. Indeed, when human behavior so clearly determines the "validity" of the "niche," we believe that it is ethically complacent and irresponsible to assume that the only choices are animal experimentation or extinction.

\section{(4) THE ACCEPTABILITY OF HARMS}

Heffner recognizes that not all research animals benefit individually from their laboratory existence given that "most research animals die without breeding" (2001). His response to this is that it is no different from what happens to animals in the wild, and that in fact their laboratory existence is considerably more comfortable than in the wild. As he puts it, "We protect domestic animals from the ravages of the wild and in return make use of those that would otherwise have died" (Heffner 2001). Again, the parallels to justifications of slavery in the Americas are chilling: many slaveholders thought that they were providing their human "property" with the benefits and comforts of "civilization" (such as it existed on the plantations) and that this justified them in transporting Africans to America and keeping them (and their offspring) as slaves, rather than leaving them to face the mortal risks of life in tropical Africa. We must not be misunderstood here as saying that the practices of slavery and laboratory experimentation are morally equivalent, or that Heffner personally endorses slavery. Our sole point is that the arguments presented by Heffner parallel those used fallaciously to justify slavery and are correspondingly invalid. (For a discussion of the faulty logic associated with justifying using laboratory animals for education or research based on the "nature's cruelty" see Bekoff 2000 and in press.)

Heffner also discusses the morality of sacrificing some to benefit others and points out to his students that they all accept 30,000 human deaths per year in the U.S. as the cost of obtaining the benefits of automobiles. He writes, "In short, if we accept for ourselves the principle that some will inevitably suffer so that we can enjoy the advantages of private transportation, can we then prevent animals from a similar arrangement that ensures their survival?" But there are many relevant disanalogies here: we choose to drive - animals do not choose to enter the research stream; nobody designates which drivers will die in accidents - humans do designate which animals will die in experiments; and so on. These disanalogies point to our much greater complicity in the fate of animals, and correspondingly greater responsibility for their well-being. 


\section{CONCLUSION}

We have argued that all four steps in Heffner's program for justifying animal experimentation are weak. We are particularly concerned by the consequences of using this approach in the classroom, as recommended to Heffner's fellow psychologists in his American Psychological Society Observer article. Bad arguments do more harm than good by failing to properly prepare students to engage in effective debate. A better approach might involve consulting a qualified ethicist or inviting such a person to come to the classroom to frame the discussion, but at the very least the ethics of animal experimentation deserve a more balanced treatment that focuses on the costs and benefits of specific experiments. Anything less does a disservice to students, whichever side of the issue they start from.

\section{ACKNOWLEDGMENTS}

We are grateful to two anonymous referees for helpful suggestions on an earlier draft of this paper.

\section{REFERENCES}

Bekoff, M. ed. 1998. Encyclopedia of Animal Rights and Animal Welfare. Westport, CT: Greenwood Publishers.

Bekoff, M. 2000. Strolling with Our Kin. New York: Lantern Books.

Bekoff, M. In press. Minding Animals: Science, Nature, and Heart. New York: Oxford University Press.

Gruen, L. 1993. Animals. In A Companion to Ethics, 343-353, ed. P. Singer. Oxford: Blackwell.

Heffner, H. E. 1999. The symbiotic nature of animal research. Perspectives in Biology and Medicine 43(1): $\quad$ 128-139. (Updated version at http://www.utoledo.edu/psychology/hheffner/thesymbioticnatureofani.pdf.)

Heffner, H. E. 2001. Animal research in the college classroom. American Psychological Society Observer 14(3): $\quad$ p.5 and p.31. Available http://www.psychologicalscience.org/observer/0301/animal.html.)

Rollin, B. E. 1992. Animal Rights and Human Morality. (Revised edition.) Buffalo, NY: Prometheus Books. Sapontzis, S. F. 1987. Morals, Reason, and Animals. Philadelphia: Temple University Press.

Varner, G. 2000. Sentientism. In A Companion to Environmental Philosophy, 192-203, ed. D. Jamieson. Oxford: Blackwell. 